\title{
Roles of Actors in Palm Oil Value Chain: a Paradox
}

\author{
Firda Hidayati ${ }^{\text {a }}$, Irwan Noor ${ }^{\text {a }}$, Akhmad Amiruddin ${ }^{\text {a }}$ \\ ${ }^{a}$ Brawijaya University, Malang, East Java, Indonesia
}

\section{INFORMASI ARTIKEL}

\section{Article history:}

Date Submission: 11 July 2019

First revision: 16 August 2019

Accepted: 31 July 2019

Available online: 31 August 2019

Keywords: palm oil value chain, smallholders, welfare

\section{ABSTRACT}

Process of globalization has added pressure to smallholder palm oil in world palm oil producers countries. The globalization, however, create opportunities for small palm oil holders to benefit from it whenever they are able to collaborate proportionally with other actors. In order to do so, this study is aimed to elaborate the current value chain and typology of smallholders to establish the suitable collaboration schema. The finding showed that although there is imperfect quality of role, the variety of actors involved make smallholders found a better role. The PTPN VIII Kertayaja (State-Owned Enterprises (SOE) should be able to gain benefit and opportunities from suggestion use of the collaboration with other actors within the value chain. However, it is the role of SOE that act as state fiscal-revenue collector as well as maintaining status quo and having coercive power but it makes them complacent it and neglect to achieve sustainability role in empowering farmers. On the other hand, willingness to maximize the benefits created from the transaction has led head of village, private enterprises, collectors, sellers and transporters to find the most innovative way to help the small plantation owner to ease the challenges and maximize their roles in adding value to the chain.

\section{INTISARI}

Proses globalisasi telah menambah tekanan pada petani kecil di negara-negara produsen minyak sawit dunia. Akan tetapi, globalisasi menciptakan peluang bagi pemegang minyak sawit kecil untuk mengambil manfaat situasi tersebut jika mereka dapat berkolaborasi secara proporsional dengan aktor-aktor lain. Penelitian ini bertujuan untuk menguraikan rantai nilai saat ini dan tipologi petani kecil untuk membangun skema kolaborasi yang sesuai. Temuan ini menunjukkan bahwa meskipun peran yang tidak sempurna, berbagai pelaku yang terlibat membuat petani kecil menemukan peran cukup baik. Disamping itu peran Badan Usaha Milik Negara (BUMN), PTPN VIII Kertayaja harus dapat memperoleh manfaat dan peluang dari penggunaan kolaborasi yang bijak dengan aktor-aktor lain dalam rantai nilai. Namun, peran BUMN yang bertindak sebagai pengumpul pendapatan fiskal negara serta mempertahankan status quo dan tetap menggunakan kekuatan coercive yang menghambatnya untuk mencapai peran keberlanjutan. Di sisi lain, aktor-aktor yang berpengaruh seperti kepala desa, perusahaan swasta, pengumpul, penjual dan pengepul menemukan cara inovatif untuk membantu pemilik perkebunan kecil untuk meringankan tantangan dan memaksimalkan peran mereka meningkatkan manfaat dalam jaringan mata rantai sektor kelapa sawit. 


\section{Introduction}

The small-scale palm oil farmer has been supporting the socio-economic growth of Indonesia and Malaysia as the top world palm oil producer (Paspi, 2017). After the agreement between Indonesia and IMF in 1988, palm oil investment was sourced in part domestically but also more frequently come from neighboring countries, especially Malaysia and Singapore (Varkkey, 2016). This shows palm oil in Indonesia and Malaysia involve regional and multinational developments that affect socio-economic growth in palm oil region. The importance of palm oil industry to social and economic growth will be less significant if the government policy is not suitable to ensure smallholders growth.

Studies on impact of smallholders palm oil plantation to socio-economic development in most countries have showed a positive result. Every smallholder cultivating less than 2 hectares of land which is estimated to managed $84 \%$ of the total world's farms (Lowder et al., 2016). Although most smallholders in developing countries are involved primarily in subsistence-based production, in fact, they have the role of commercialized global value chains globalization and rising global trade flows in recent decades (Lee et al., 2012; Rigg et al., 2016). Current concerns over the appropriate modes and effects of smallholder participation are raising due to changing rules and relations in many of these global value chains. For example, new barriers to smallholder market participation is created from the proliferation of safety and quality standards, quality-based competition and rising market concentration that in turn increasingly shifting power relations between farmers and processors/retailers which giving more benefit to processors /retailers (Lee et al., 2012; McCullough et al., 2008). Without government support commercial smallholder therefore, are facing a huge challenges to meet world sustainable production standards. However, it is difficult to embark upon a specific and targeted policy for the wide range of actors they represent and issues they face as public statistics and discourse tends to treat 'smallholders' without any specification (e.g. DJP, 2015) or based on a dichotomy of company-assisted and independent smallholders (e.g. Brandi et al., 2015; Euler et al., 2016; Lee et al., 2013). Therefore, there is a need to use specific directed policy using specific smallholders attribute and more actor-disaggregated interventions (Fan et al., 2013).

This research focuses on smallholder oil palm farmers in Indonesia, which account for an estimated $40.8 \%$ of the total Indonesian oil palm acreage (DJP 2015). The dynamic within Indonesia's palm oil sector has been illustrate the challenges faced by the smallholder. For example, current global warming has put pressure on most major palm oil buyer to demand compliance with certification system such as Roundtable Sustainable Palm Oil (RSPO). Poor social and environment performance (e.g. Enrici and Hubacek, 2016; Obidzinski et al., 2013) has forced most major buyer to ban Indonesia's palm oil products. Moreover, major chain actors are augmenting these requirements through zero-deforestation commitments, which aims to eliminate deforestation and peatland conversion from their entire supply chain (Pirard et al., 2015). In an attempt to respond to the demand and to enhance the global competitiveness of Indonesian palm oil, the Indonesian government has also developed a mandatory public standard, the Indonesian Sustainable Palm Oil (ISPO) system. Despite the critic that ISPO attempts to undermine the more encompassing private standards (McCarthy et al., 2012), the need to comply with the various standards has placed increasing demands on sustainability and legality of Indonesia's oil palm smallholders. However, independent smallholders are currently poorly equipped to comply with standards (Hidayat et al., 2015; Rietberg and Slingerland, 2016) and without adequate support, many smallholders threaten to isolate from both domestic and global palm oil markets (Cramb \& McCarthy, 2016; Lee et al., 2012).

Recognizing that many palm oil smallholders lack compliance capacity, but there is an urgent need for the government to intervene in governing the palm oil sector to control the global market. The policies should involve development agencies, corporations, and multistakeholder initiatives for a proper designing initiatives to address compliance barriers and enhance smallholder competitiveness. For example, an attempt to design moratorium on new palm oil permits. A moratorium plan restricting the granting of new permits for the expansion of palm oil plantations and mining is proposed by Indonesian President Joko Widodo. This policy tries to minimize the extent of forest and land resource as well as to promote environmental preservation. Indonesian Sustainable Palm Oil System (ISPO) which has been implemented since 2011 is revitalized since 2015 under new regulation 61/2015 on collection and use of palm oil Fund. The government also proactive to discover nontraditional buyer to secure the buyer for the abundant palm oil product, especially when traditional buyer reduce the amount of palm oil demand. However, the policy may prompt to failure if there is no comprehensive information to treat smallholder based on the actor, issue and socio-economic characteristic.

This study attempt to develop typology of smallholders that reflects large advantages for smallholder of palm oil development. Leuwipuh Village, Banjarsari sub-district, Lebak District, Banten Province is selected because it has a smaller area of a plantation, good quality of the road, closer to the market, closer to the palm oil industry, closer to the nation's capital and 
closer to metropolis city. Proper infrastructure is believed to increase the development of smallholder oil palm (Belcher et.al 2004). The actor and its role that construct the palm oil sector, some barriers that hampers smallholder participation in social-economic development, and some supports that easy smallholder participation in social-economic development, as well as policy and regulation that influence the development of small holders in palm oil sector will be revealed. The palm oil private enterprises, palm oil state-owned enterprises, collectors, intermediate people, small palm oil owner and laborer are investigated to explore the relationship. The finding will be helpful for the government to construct more appropriate policy that will support smallholder palm oil to participate in world sustainable palm oil value chain demand

In order to construct a model of smallholder palm oil in Banten, this research attempt to propose below research question: How are role of actors in the smallholder palm oil sector in Leuwipuh Village, Banjarsari sub-district, Lebak district, province of Banten? and Do money, bureaucracy, and capacity hindering the PTPN VIII Kertajaya to strengthen the smallhoder participation for social-economic development?.

\section{Theory}

\subsection{Governance Structure: Global Value Chain (GVC) Approach}

Existence of large retailers, merchandisers and buyers which dominate decentralized, global-scale modes of organizing production have form a literature that focuses on the factors that shape governance structures within global value chains (Coe et al., 2008, Gereffi et.al., 2005, Humperey \& Smith, 2002). Vermeulen, \& Cotula (2010) posed that smallholder consent, and recompense in large-scale land deals for biofuels projects in Africa significantly reduce conflict that impede the value chain. Using Global Value Chain (GVC) approach implies analyzing the actors within a GVC, to grasp better understanding of the wider institutional context and its dynamics. This suggests the need for better analysis of how governance structure is affected by the relative power of actors within global production network shift power overtime (Coe et al., 2008).

Further, critics identified a need for more careful study of the national and local sections of Global Production Networks (GPNs)-where localized networks of power and interest coalesce and articulate in specific ways. It is necessary to analyze specific "tactical and strategic alliances" working in national and local domains as opposed to assume the dominance of lead firms (Fold, 2008).

\subsection{Agribusiness Risk}

As suggested that the state has limited capacity, the "policy networks" can work as "mechanisms of political resource mobilization," especially where policy resources and capacity are "distributed or dispersed among private and public actors" or are "context (or actor) dependent." (Humphrey \& Schmitz, 2002). This policy network analysis is important in this research as partnership in Indonesia's palm oil sector is crucial.

The partnership in GVC literature has lead to "imperfect quality" as firms tend to favor governance structures that minimized risks such as supply chain failure and damage to brand reputation (Humphrey \& Schmitz, 2002; Vogel, 2008). Understanding the governance of palm oil industry in Indonesia cannot be separated with increasing investment in palm oil sector. The increased salience of questions of risk and opportunity, the ascent of new, more market based policies, and the state's reduced power to dictate the terms of agribusiness investment has affected dynamic of the industry (Casson, 2000). The industrial policy has been directed by these questions framed the context for a debate among policy makers and plantation investors (Zen et al., 2005).

Microcredit or cooperative scheme is important tools for networking. The dynamic of smallholders in developing countries have been strengthened with the existence of co-operative institution as a mechanism of financial collective action to reduce agriculture risk (Matin, Hulme \& Rutherford, 2002). The dynamic of Indonesian's microfinance institution has been dominated by for-profit state-owned and private commercial banks have a dominant role, with little involvement by NGOs (Charitonenko \& Afwan 2003). Such initiatives showed the significance importance of government role in mitigating agriculture risk in Indonesia.

\subsection{Regime Interest}

Remote agrarian regions shaped by state interest and regime interest. A regime consist of the three broad elements: Dominant coalition of socio-economic; institution of politic and economic is the way to get power; and the public policy profile (Pempel, 1997). The state can use dominant socio-economic coalitions to promote the interests of private individuals and specific social forces. Increasing regime power is unavoidable since the state comprises of a set of institutions through which power is exercised, and upon which a regime's power ultimately depends. As theorists of predatory regimes in Africa note, while regime continuity can depend on the strength of the state, we cannot assume that state formation is compatible with regime consolidation (Eriksen, 2005:339). The position of state based elites is 
often shaped by a simple question: What do they need to do to survive politically? (Grabowski \& Self, 2006).

Some opinion believe that effective state will be shape by state dependency to tax collection from population. This condition require the state to have communication, communication, and bargain with citizen to decided tax rate (Moore, 2004; Ross, 2001, Tilly, 1975). State will develops the infrastructural power to manage and control state fiscal and it open negotiation arrangement with citizen to ensure revenue power. In the processes of negotiation arrangement consist of state power, accountability, participation, and legitimacy. Here, smallholder development schemes in marginal areas will occur cause regime interest have some desire to empower the state capacity of rural development and state revenue. In other hand, the state has different way to get revenue such as depend on state control of commodity export surpluses may keep rural populations quiescent in areas integral to the functioning (or expansion) of the commodity export economy, rather than developing agriculture to improve rural welfare. This situation will make regime interest close possibility to communicate with citizen and the regime don't have high interest in remote agrarian region.

On the one hand, districts may obtain large revenues from oil or mineral resources or from lucrative export commodities. On the other hand, districts may have subsistence orientated or low productivity agriculture and will depend upon fiscal transfers from the center. In both cases, this logic suggests that state-based elites will look elsewhere for the resources required for their endurance. Accordingly, they will have little incentive to develop agriculture or look after the welfare of poor agriculturalists (Grabowski \& Self, 2006). In both cases, despites different political economies, small farmer will tend to have low bargaining power.

\section{Research Method}

This research used qualitative approaches. Qualitative designs emphasize understanding of social phenomena through direct observation, communication with participants, or analysis of texts, and may stress contextual subjective accuracy over generality. This design is selected because researcher attempt to seek for full contextual understanding of an individuals' social actions.

The interview, observation and triangulation were conducted for 3 (three) months to assure the quality of data. The informant is selected based on their roles as:

a) Member of palm oil private enterprises: PT Globalindo Agro Lestari;

b) Small palm oil plantation owner;

c) Laborer;

d) Member of state Owned Enterprises-SOE;

e) Head of village; f) Middleman: collector, transporter, seller;

g) State-owned bank: Bank Rakyat Indonesia; and

h) Dinas Pertanian dan Ketahanan Pangan (Agriculture and Food Security Agency).

\section{Results and Discussion}

The palm oil value chain in Leuwipuh Village is determined by relative power exercised between several actors involved. The of head of village smallholders plays important role in leading owner consent due to his formal and informal power. He hold higher political power since he is also one of the owner that fought for legality of the land. The formal legal right of land is the most important aspect for laborer, middleman and owner to maximize benefits from the palm oil plantation. The ignorance of the right owner took place due to their misunderstanding of the value of the palm oil. When state through PTPN VIII ordered to convert the land for palm oil, no one dare to disobeyed it but then they also given the right of land to other people due to their believe on useless value of palm oil. It took years of time and abundance patience to consolidate the right of land to the proper owner. As the communalism is strong in the village, it is the task of the head of village to consolidate it. The increasing price of palm oil has been too lucrative and lure many people to invest on it.

As the number of plantation has been growing significantly, middleman have gain significant role on the value chain. The collector has taken a higher role for offering the cash whenever the collect the fresh palm oil fruit from the owner. PTPN VIII Kertajayaas was the main partner of the owner, but it was no longer be the main partner for three reason. First, the PTPN VIII Kertajaya only received small amount of fresh fruit and it has been significantly reduced after the fire took place in the manufactory. It prioritized the fresh fruit from their own plantation. Second, it took at least two week for the owner to receive the payment for the fresh fruit submitted to the manufacture. Third, the existence of PT Globalindo Agro Lestari that has not set limit on how much fresh fruit from the plnatation. Therefore, owner prefer the middleman to buy their product, even though they have to receive less money due to additional cost subjected to the purchase price. The transporter, and seller also join the increasing role. They have been helped the collector to transport and sell the fresh palm oil fruit to other location where price is higher than in Leuwipuh village. The collector, transporter and seller are working based on mutual trust, once the selected transporter and seller caught dishonest with the volume and price of transported product, they will be drive away from the collaboration.

Unsurprisingly, the PTPN VIII Kertajaya has limited role in the value chain. The role is mostly characterized by slow response, unwilling to change, and unwilling to serve the people. It serve only to the state for meeting 
demand to the fresh fruit and crude palm oil production. It has not elavate their capacity to utilize the unprocessed product that is could not be processed using the old and low maintenance machinery. The main role is driven by the political reason to secure power through the fiscal revenue and infrastructure investment role. The state given preliminary right to the PTPN VIII Kertajaya to collect fee as being the guarantor for the smallholder palm oil plantation to borrow money to the selected Stateowned bank that has the capacity on how to minimize the non-performing loan risk. By doing so, the PTPN VIII has the fiscal source as well as authority over the citizen. The investment in infrastructure also proven to be significant in securing their power. Plantation area of PTPN VIII Kertajaya has risen from 1.769,72 hectare in 2004 to 9.795 hectare in 2014 that produces 17.254 ton of fresh fruit a year. The revenue is also secured through the investment on main processed plant building, paved and non-paved road to the plant and plantation as well as external investment, i.e. rebuild road in community that destroyed by flood. Physical and non-physical factors have led to their decreasing roles of PTPN VIII Kertajaya in the palm oil value chain. The Palm oil value chain does not allow bigger room for smallholders palm oil empowerment due to limited access given by the PTPN VIII. The PTPN VIII Kertajaya only accept farmers who have license to supply palm oil with minimum 5.000 kilogram of fresh palm oil in every week. Therefore, smaller (produce less than $5.000 \mathrm{~kg}$ ) smallholders palm oil have no bargain power over the price and quality because they can only sell their product on the licensed farmers.

Dinas pertanian dan ketahanan pangan (Agriculture and Food Security Agency) has been maintained its role a service provider. The agency has focused it effort to provide a range of training for the farmer. It range from how to open the plantation, select the best quality of seed, select the proper fertilizer until harvesting method. However, this institution has not able to secure its role due to the inability to provide sustainable and reliable training. Only few has received adequate training with infrequent schedule proper trainer. This institution does not focus on assisting some more inovative way to enhance the palm oil effectiveness and efficiency. There are no training on inovative technology such us watering and fertilizing system as well as picking method that will enhance the fruit bunch efficiency. The field trainer already ackowledge the need but fail to provide such a specific raining and education due to lack on capacity. As a result, the agriculture risk borne by the smallholder due to the expected profit to cover high cost of production could not be achieved. Interestingly, this institution is assigned to held responsible for collecting the smallholder proposal for replanting microcredit scheme which is not their traditional responsibility. The state on
2018 launch new replanting credit schema specifically for smallhoders (Kredit usaha Rakyat/KUR) with $7 \%$ interest within 5 years grace period which was paid after the harvest and given maximum IDR 25 million per hectare without guarantee.

The existence of PT. Globalindo Agro Lestari has been useful to increase the palm oil value chain. Even though, it has 20.261 hectare of plantation which produce 34.466 ton a year, it has been able to absorb majority of the fresh palm oil fruit production from the smallholders palm oil plantation. With high capacity and new and modern equipment, this private plant has been able to increase the value chain of palm oil. The decrease price of palm oil has led the choice to only sell the fresh fruit production within area due to unreasonable price to transport outside island. Previously, when the price was higher in outside island, the middleman chose to sell the fresh fruit production to Lampung city, even tough they had to deal with shipment process. The benefit still accrued after excluded all related shipment and truck transportation cost. Since the opening of PT. Globalindo Agro Lestari for 7 days a week, and the price on outside island is no longer attractive, the collector chose to sell the fresh fruit to the factory. The private enterprises and middleman have established a new tactical relationship that flourish the value chain.

The owner of palm oil plantation has been rising important role these years. It shows from the investment in plantation. In 2014, there is 7.745 hectare of palm oil plantation which produces 10.133 ton of fresh fruit a year. The owner has small area of plantation that range from 500 hectare to 1,000 hectare. They develop the power in value chain through their ability to pay for education, health and social sectors. However, during the years, only the biggest player who owner larger plantation area that significantly plays their role in value chain. The PTPN VIII Kertajaya which was the sole buyer for fresh fruit has defined the owner role. It received the fresh fruit production collectively under one biggest name. Therefore, smaller plantation owner has less bargain power, since they are not the one who receive the money. The biggest player will distribute the money that paid 23 week later to the rest of the collective member. As these situation has been established for years, the bigger players receive bigger roles in value chain.

The role of laborer is crucial as the main extractor in plantation especially with the existence of old palm oil age (more than 25 years old). The longer the age the higher the palm oil and the higher risk to extract the fresh fruit. As the new private factory has build, the role of laborer has increased especially in the non-government owned plantation. Before the private enterprise build, non-government plantation owner has reluctant to employ labor since no plant will absorbed the production. Since there is abundant and cheap labor wages, labour is 
chosen than machine. However, their value is depend on the demand for manual labor for fresh fruit extraction.

The state owned bank (SOB) and co-operative have been maintaining their role as financial provider. Their role has been secured since huge investment is required to open palm oil plantation, grow, and replantation. Currently palm oil replantation policy is ongoing at national level after evaluating the significant drop in productivity of national palm oil production that is mainly older than 25 years of age. The role of Bank Rakyat Indonesia (BRI) as SOB has been secured throughout these years since it has been assigned as the only financial institution to redistribute the state money to fund micro scheme for national palm oil plantation and replantation scheme. The funding will distribute though co-operation funded by farmer to reduce the risk of unpaid loan. The microfinance scheme which aimed to small land-palm-oil-owner is attractive enough since it provide about one third of the replantation fund need, with no payment for 5 years. The role of BRI has been strengthened by the availability of funding which has produced from increasing trend of the exported palm oil tax. Beside financial provider for smallholder, it also act as the major financial institution for the rural area. Therefore, not only smallholder but also collector, seller and transporter should highly depend on BRI. The BRI's and co-operative's role are believed to be higher in the future in palm oil value chain as in the future the need of energy and food will highly rely on palm oil. Interestingly, the institution does not provide assistance to form a community microcredit which should minimize the agriculture risk of non-performing loan since the new microcredit for palm oil replanting consist of high risk loan. i.e. no asset guarantee, payment after harvest, and long grace period.

\section{Conclusion}

This study is supported Vermeulen, \& Cotula (2010) notion on smallholder consent, and recompense in largescale land deals present to reduce conflict and therefore increase effectiveness of chain. The significant head of village, private enterprises and middleman roles have supported the localized networks of power and interest coalesce and articulate in specific ways. The previous dominant actor, PTPN VIII kertajaya has defeated by the coalition between those three actors. It is described specific "tactical and strategic alliances" working in national and local domains as opposed to assume the dominance of lead firms (Fold, 2008), the "policy networks" which work as "mechanisms of political resource mobilization," (Humphrey and Schmitz, 2002).

As it is expected, the partnership in palm oil value chain in Leuwipuh village has lead to "imperfect quality" (Humphrey \& Schmitz, 2002; Vogel, 2008). PTPN VIII Kertajaya tends to favor governance structures that minimized risks such as supply chain failure within their own institution. The existence of PT Globalindo agro Lestari supported Casson (2000) on more market based policies, and the state's reduced power to dictate the terms of agribusiness investment.

The decentralization is proven to bring benefits to balance the dominant state power. This study showed evidence that more effective states tend to emerge when the state depends on the revenue it can extract from its populations that creates a need for the state to interact with and bargain with its citizenry about the conditions and means of taxation (Moore, 2004; Ross, 2001; Tilly, 1975) or "fiscal state" (Mann, 1988). Since 1998, PTPN VIII Kertajaya was the sole buyer for the smallholders plantation owner, during these years the institution has been established such dictate bargain power over citizen. They has been able to collect $5 \%$ fee for the total bought product while at the same time has been delayed the payment for 2-3 weeks. With the existence of PT Global Agro Industri, middleman took control over where to sell the fresh fruit. This supported the notion of legitimate, participatory and institutionalized civic processes replacing more coercive forms of governance (see Bates, 2001).

Further, where state based elites have vested interests in a rural industry, they are likely to invest in building infrastructure. The PTPN has been heavily invest on road, building, and social infrastructure. It proven Erikson (2005) notion on. Remote agrarian development will occur when regime interest had need to empowering their capacity in regime consolidation and regime economic to increasing their revenue mechanism and secure state power.

At the end financial, capacity and bureaucracy aspects determine the quality of value chain. Dinas pertanian dan ketahanan pangan and PTPN VIII Kertaya could not maximize their role in the value chain. They are hampered by the low capacity and high bureaucracy to be able to serve under collaboration scheme. On the other hand, BRI, smallholder owner and middleman have been able to increase the value through maximizing role in collaboration. As stated by Matin, Hulme \& Rutherford (2002), co-operative institution as a mechanism of financial collective action to reduce agriculture risk that face by smallholders. The dynamic of Indonesian's microfinance institution has been dominated by for-profit state-owned has played a dominant role (Charitonenko and Afwan 2003).

\section{References}

Bates, Robert. H. (2001). Prosperity and Violence: The Political Economy of Development. New York: Norton. 
Belcher, Brian., Rujehan., Ndan Imang., \& Achdiawan, Ramadhani. (2004). Rattan, Rubber, or Oil Palm: Cultural and Financial Considerations for Farmers in Kalimantan. Economic Botany, Vol. 58, No. 1, pp.77-87.

Brandi, Clara A., Cabani, Tobia., \& Hosang Cristoph. (2015). Sustainability Standards for Palm Oil: Challenges for Smallholder Certification Under the RSPO. The Journal of Environment \& Development, Vol. 24, No. 3 (Juli 2015), pp. 1-26.

Casson A. (2000). The Hesitant Boom: Indonesia's Oil Palm Sub-Sector in An Era of Economic Crisis and Political Change. Occasional paper No. 29. Bogor, Indonesia: CIFOR.

Charitonenko, Stephanie., \& Afwan, Ismah. (2003). Commercialization of Microfinance: Indonesia. Manila, Philippines: Asian Development Bank.

Coe, Neil M., Dicken, Peter., \& Hess, Martin. (2008). Global Production Networks: Realizing The Potential. Journal of Economic Geography, Vol. 8, No. 3, pp.271-295.

Cramb, R., \& McCarthy, J. F. (2016). The Oil Palm Complex: Smallholders, Agribusiness and The State in Indonesia and Malaysia. Singapore: NUS Press.

DJP. (2015). Statistik Perkebunan Indonesia Komoditas Kelapa Sawit 2014-2016. Directorate General of Estate Crops, Jakarta.

Enrici, Ashley., \& Hubacek, Klaus. (2016). Business as usual in Indonesia: governance factors effecting the acceleration of the deforestation rate after the introduction of REDD+. Energy, Ecology and Environment, Vol. 1, Issue 4, pp.183-196.

Eriksen, S.S. (2005). The Politics of State Formation: Contradictions and Conditions of Possibility. The European Journal of Development Research, Vol. 17, No. 3, pp.396-410.

Euler, Michael., Hoffman, Munir., Fathoni, Zakki., \& Schwarse, Stefan. (2016). Exploring Yield Gaps in Smallholder Oil Palm Production Systems in Eastern Sumatra, Indonesia. Agricultural Systems, Vol. 146, pp.111-119.

Fan S., Brzeska, J., Keyzer, M., \& Halsema, A. (2013). From Subsistence to Profit, Transforming Smallholder Farms. Washington DC: IFRI.

Fold, N. (2008). Transnational Sourcing Practices in Ghana's Perennial Crop Sectors. Journal of Agrarian Change, Vol. 8, No. 1, pp.94-122.

Gereffi, Gary., Humphrey, John., \& Sturgeon, Timothy. (2005). The Governance of Global Value Chains. Review of International Political, Vol. 12, No. 1, pp. 78-104.

Grabowski, Richard., \& Self, Sharmistha. (2006). Agricultural Development, State Effectiveness and Long-Run Economic Development. Discussion
Papers, Paper 45. OpenSIUC (Southern Illinois University Carbondale), US.

Hidayat, Nia Kurniawati., Glasbergen, Pieter., \& Offermans, Astrid. (2015). Sustainability Certification and Palm Oil Smallholders' Livelihood: A Comparison between Scheme Smallholders and Independent Smallholders in Indonesia. International Food and Agribusiness Management Review, Vol. 18, Issue 3, pp.25-48.

Humphrey, J., \& Schmitz, H. (2002). How Does Insertion in Global Value Chains Affect Upgrading in Industrial Clusters?. Regional Studies, Vol. 36, No. 9, pp.1017-1027.

Lee Joonkoo., Gereffi, Gary., \& Beauvais, Janet. (2012). Global Value Chains and Agrifood Standards: Challenges and Possibilities for Smallholders in Developing Countries. Proc Natl Acad Sci USA, 31 Jul 2012, pp.12326-12331.

Lee, Janice Ser Huay., Ghazoul, Jaboury., Obidzinski, Krystof., \& Koh, Lian Pin. (2013). Oil Palm Smallholder Yields and Incomes Constrained by Harvesting Practices and Type of Smallholder Management in Indonesia. Agronomy for Sustainable Development, Vol. 34, No. 2, pp.501513.

Lowder, Sarah K., Skoet, Jakob., \& Raney, Terri. (2016). he Number, Size, and Distribution of Farms, Smallholder Farms, and Family Farms Worldwide. World Development, Vol. 87, pp.16-29.

Mann, Michael. (1988). States, War and Capitalism: Studies in Political Sociology. US: Blackwell.

Matin, Imran., Hulme, David., \& Rutherford, Stuart. (2002). Finance for the Poor: From Microcredit to Microfinancial Services. Journal of International Development, Vol. 14, No. 2, pp.273-294.

McCarthy JF., Gillespie P., \& Zen Z. (2012). Swimming Upstream: Local Indonesian Production Networks in "Globalized" Palm Oil Production. World Development, Vol. 40, No. 3, pp.555-569.

McCullough E., Pingali, P.L., \& Stamoulis, K.G. (2008). The Transformation of Agri-food Systems: Globalization, Supply Chains and Smallholder Farmers. London \& Sterling, VA: FAO and EarthScan.

Moore, M. (2004). Revenues, State Formation, and The Quality of Governance in Developing Countries. International Political Science Review, Vol. 25, No. 3, pp.297-319.

Obidzinski, Krystof., Takahashi, Ikukho., \& Dermawan, Ahmad. (2013). Can Large Scale Land Acquisition for Agro-Development in Indonesia be Managed Sustainably?. Land Use Policy, Vol. 30, No. 1, pp.952-965.

Paspi. (2017). The Myths Vs Facts of Indonesia's Palm Oil Industry in Social, Economic and Global 
Environmental Issues. Bogor: Palm Oil Agribusiness Strategic Policy Institute.

Pempel, T.J. (1997). Regime Shift: Japanese Politics in a Changing World Economy. Journal of Japanese Studies, Vol. 23, No. 2, pp.333-361.

Pirard, Romain., Fishman, Akiva., Gnych, Sophia., Obidzinski, Krystof., \& Pacheco, Pablo. Eforestation - Free Commitments: The Challenge of Implementation - An Application to Indonesia. Working Paper. Center for International Forestry Research (CIFOR), Bogor.

Rietberg, Petra., \& Slingerland, Maja. (2016). Barriers to Smallholder RSPO Certification-A Science-forPolicy Paper by the SEnSOR Programme. Wageningen, the Netherlands: Wageningen University.

Ross, M. L. (2004). Does Tax Lead to Representation?. British Journal of Political Science, Vol. 34, pp.229-249.

Tilly, C. (1975). The Formation of National States in Western Europe. Princeton University Press, New Jersey.

Varkkey, Helena. (2016). The Haze Problem in Southeast Asia: Palm Oil and Patronage. London \& New York: Routhledge.

Vermeulen, Sonja., \& Cotula, Lorenzo. (2010). Making the Most of Agricultural Investment: A Survey of Business Models that Provide Opportunities for Smallholders. FAO \& IIED, Rome, Italy.

Vogel, D. (2008). Private Global Business Regulation. Annuиal Review Political Science, Vol. 11, pp.261-282.

Zen, Zahari., Barlow, Colin., \& Gondowarsito, Ria. (2005). Oil Palm in Indonesian Socio-Economic Improvement A Review of Options. Available at https://ccep.crawford.anu.edu.au/acde/publication s/publish/papers/wp2005/wp-econ-2005-11.pdf [Accessed on 10 January 2019]. 